\title{
Printed for Performance: Ceremonial and Interactive Aspects of Books from Europe's First Presses
}

"O Rare! Performance in Special Collections." I will admit that when the theme for the 2013 RBMS preconference was announced, I assumed that all of the papers would come from colleagues who work directly with performing arts collections. Given that I work at Perkins School of Theology at Southern Methodist University, it might have been more promising for me if, instead of beginning " $\mathrm{O}$ Rare," the title had begun "Orare," the Latin verb to pray. But then I considered the first words of the conference abstract: Libraries house performance. Although the focus of the library where I work is not theater, film, music, or dance, it occurred to me that some of the most important treasures that we house, midfifteenth-century books from the earliest presses in Mainz, Germany, were most definitely printed for performance-religious performance, public performance, or classroom performance-where "performance" is defined simply as the reading of a text aloud for others who will derive a spiritual, social, or educational benefit from hearing it.

Although these earliest of all printed books have been the subjects of intensive research into their significance within the history of typography, their performative aspects have rarely been noticed, much less studied in detail. ${ }^{1}$ Given that performance was such an important aspect of later book production, this paper will explore how these early books, harbingers of a worldwide revolution in communications, were designed and prepared so that they could function within their intended interactive, public, or ceremonial context. My evidence in this study will not be fifteenth-century accounts or documents, which are all too rare for the period in question. Instead, I will focus on the physical characteristics of the surviving specimens themselves to argue that they were printed for use during performance, or at least to fulfill interactive functions for groups of users, as opposed to silent readers.

1. One exception is the discussion of the use of the Gutenberg Bible in monastic reading; see Paul Needham, "The Changing Shape of the Vulgate Bible in Fifteenth-Century Printing Shops," in The Bible as Book: The First Printed Editions, eds. Paul Henry Saenger and Kimberley Van Kampen (London and New Castle, Del.: The British Library and Oak Knoll Press, 1999), 53-70. 
The chronological overview of early printed editions presented in this article will range across the first decade of European typography, ca. 1450 to 1459, focusing by necessity on the presses of Johannes Gutenberg and his colleagues in Mainz (no printing from any other European town is known until 1460). These editions include the Sibyllenbuch of ca. 1450-1454, the Türkenkalendar of late 1455, various editions of the Donatus from the early 1450s, the Gutenberg Bible of ca. 1455, a fragmentary liturgical Psalter of ca. 1456 or so, the Psalterium cum canticis of 1457, the Canon missae of ca. 1458, and the Psalterium Benedictinum of 1459, each of which manifests clear evidence of its use in various forms of performance, as opposed to independent study. In fact, printed books intended exclusively for silent reading were virtually unknown during this period; no book of significant length printed for this purpose is known until shortly after the publication of the Psalterium Benedictinum in 1459. The article will conclude with one special case study from slightly later, a liturgical book printed outside of Mainz ca. 1473, which is the first known instance of European music printing.

\section{The Sibyllenbuch}

The first book printed in Europe with movable types generally is understood to be the Gutenberg Bible of ca. 1455. ${ }^{2}$ It is Europe's first substantial printed book, the first large-scale demonstration that the new typographic art could be used to create hundreds of well-made copies of the classic works of Western civilization for preservation in libraries across Europe. However, it had several predecessors, smaller books and ephemeral works that were produced as the new techniques were worked out at the first Mainz press. Perhaps the earliest of all of these is the German poem called the Sibyllenbuch, a mere fragment of which, discovered at Mainz in 1892, has been one of the most celebrated treasures of the Gutenberg Museum in Mainz since 1903. ${ }^{3}$ Discarded centuries ago, the book whence it came was cut apart for use as a bookbinder's waste material, and thus the precious printed paper fragment endured a second life as a recycled scrap of protective covering inside the binding of some other book. The size of a postcard, the fragment bears only 28 verses of the Sibyllenbuch. Although no other trace of this printed edition survives, its entire text of 1,040 verses is known from fourteenth-century manuscripts. The Sibyllenbuch recounted various prophecies of an ancient sibyl concerning the Holy Roman Empire that would be fulfilled at the time of the Last Judgment. On the evidence of the length of the poem, the orientation of the paper, and the size of

2. Biblia latina (the "Gutenberg Bible" or "42-Line Bible") [Mainz: Johannes Gutenberg, for Johann Fust, ca. 1455, before 15 August 1456]. Nearly every fifteenth-century European book printed with movable types is described, with further literature, in Incunable Short-Title Catalogue (London: The British Library, 1980-in progress), accessible via the British Library website, cited hereafter as "ISTC." The Gutenberg Bible is ISTC ib00526000.

3. Sibyllenbuch ("Weltgericht" or "World Judgment") [Mainz: Johannes Gutenberg(?), ca. 1450-54?]; see ISTC is 00492500 . 
the typeface, the Sibyllenbuch must have been a booklet in large quarto format that consisted of 18 or 19 printed leaves. The text was printed by means of a large Gothic typeface that imitated the script that contemporary scribes used to write Missals, Bibles, and other liturgical books. This same Gothic typeface was used to print several other ephemeral works that can be localized to Mainz and dated to the mid 1450s. However, the typography seen in the Sibyllenbuch betrays uneven alignment and spacing. These imperfections are not present in the beautifully printed Gutenberg Bible of ca. 1455, which used a slightly smaller and neater Gothic typeface. This suggests that the Sibyllenbuch should be dated as early as possible, from ca. 1450 to 1454 at the latest, with the coronation of Frederick III as the Holy Roman Emperor in 1452 offering a plausible political occasion for the publication.

Let us now consider how the Sibyllenbuch was read. The printed capital letters of each verse were highlighted by an early owner in red ink to help the reader locate the beginnings of each verse (at this early moment in typographic history, the verse endings do not yet coincide with the line endings). As one reads the German text, it becomes quite obvious that, while the Sibyllenbuch is not exactly Shakespeare, it does manage to fall into rhyming couplets:
...leben Und mußen do hien, do got urtel wil geben. Sie gene mit schrecken dohien, Die got nye erkanten noch forchten en. Nieman mag sich verbergen nicht Vor dem gotlichen angesiecht. Cristus wil do urtel sprechen Und wil alle boßheit rechen. Die nie ge- daden den willen sin, Den wil er geben ewige pin Und wil den guden geben By ym freude und ewig leben, Sijt die werlt und alle ding, Die in der werlt geschaffen sint, Czu gene und werden auch zu nicht, Als man wol [hort und siecht]...

Now, no one in the fifteenth century sat down to read rhyming couplets alone, in silence at their desk. Artifacts of the oral culture of medieval Europe, these verses of dramatic prophecy were meant to be read publicly, out loud, to people who were deeply concerned about what the future had in store for the Holy Roman Empire. ${ }^{4}$

\footnotetext{
4. Jonathan Green, Printing and Prophecy: Prognostication and Media Change 1450-1550 (Ann Arbor: University of Michigan Press, 2012), 15-38, does not analyze the Sibyllenbuch in terms of public performance.
} 


\section{The Türkenkalender}

A second work with an oratorical function, likewise printed with Gutenberg's earliest Gothic typeface, was Eyn Manung der Cristenheit widder die Durken ("a warning to Christendom against the Turks"), commonly known as the Türkenkalender. ${ }^{5}$ Discovered at the Jesuit College of Augsburg in 1806, the unique surviving copy is now at the Bayerische Staatsbibliothek in Munich. This timely piece of political propaganda was rushed into print in December 1454 for use in the New Year 1455. I say rushed, because certain verses were inadvertently printed twice on consecutive pages; this was perhaps Western Civilization's first typographical error. The six-leaf pamphlet sounded the alarm for the European states to rally to the defense of the Christian kingdoms that were threatened by Sultan Mehmed II (the Conqueror) after the Fall of Constantinople in 1453. The date of the forthcoming year ("M.cccc.lv.") appears in Roman numerals in the bottom line of the first page. As with the Sibyllenbuch, this piece of political ephemera was printed for reading out loud, as the German text was composed in rhyming couplets. A brief illustration of this fact is provided by the final words of each of the couplets on the first page:

tron/crone
roit/not
grois/blois
gelicken/erstricken
wunden/stunden
heiden/leiden
lant/hant
usmehen/gescheen
gut/hut
schin/din
uffenbar/M.ccc.lv.iar

The Türkenkalender for 1455 was meant to be read aloud, preferably to assembled multitudes in the city square, with a note of alarm in the reader's voice, to stir Europe's Christians to action against the threat from the East.

\section{The Donatus}

Interactive aspects are also found in the most commonly printed booklets from the early Mainz presses, the Ars minor, an essential Latin school primer attributed to the fourth-century grammarian Aelius Donatus, after whom the book came to be known

5. Eyn Manung der Cristenheit widder die Durken (“Türkenkalender" for 1455) [Mainz: Johannes Gutenberg(?), probably December 1454]; see ISTC it00503500. 
simply as the "Donatus." These 12- to 14-leaf small folio grammars remained in constant demand and were read to pieces by young students. Not being booklets that a fifteenth-century librarian would bother to keep, they survive only as recycled vellum fragments recovered from later bookbindings in Mainz and surrounding towns. Their improved yet still primitive typography—using what modern German scholars have christened the "Donatus-Kalendar" types, or "D-K types" - suggests that they too were produced by Gutenberg and his associates during the early years of the 1450s. By no means was the Donatus a book intended for quiet reading enjoyment. It consists entirely of repetitious conjugations of Latin verbs. Entire classes of students would recite their conjugations aloud in unison, often from a shared copy. This traditional classroom procedure gave rise during the last decade of the fifteenth century to an iconographic tradition in which printed schoolbooks often were illustrated with various versions of the "Accipies woodcut," showing a master and his pupils, books in hand, reciting the lesson (see figure 1). The Latin legend in the scroll above the master reads "Accipies tanti doctoris dogmata sancti" ("You will receive the sacred tenets of a great doctor"); thus, the haloed master of these unpromising-looking pupils takes on the identity of the author of the text in question, whether it be Thomas Aquinas, Gregory the Great, or some other venerable theologian. All of the books printed with the "Accipies woodcut" frontispiece would have been intended, like the Donatus, for this sort of interactive classroom use.

Figure 1. Boethius. De disciplina scholarium. Cologne: Heinrich Quentell, 22 Oct. $1493, \mathrm{f} .1$ recto (detail). Courtesy of Bridwell Library Special Collections, Perkins School of Theology, Southern Methodist University.

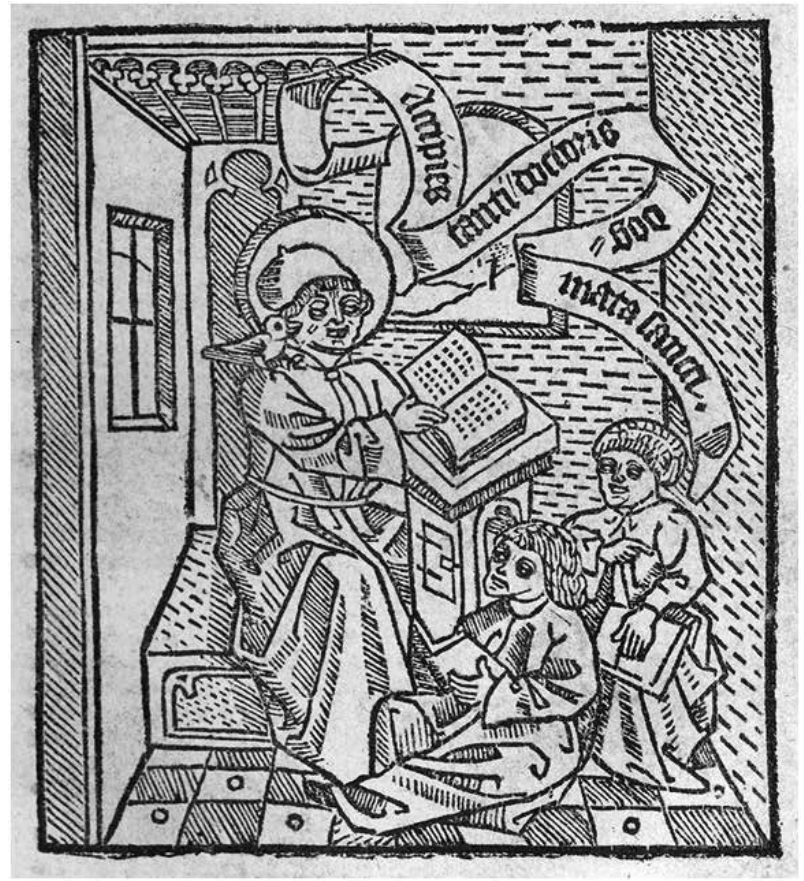

6. Aelius Donatus, Ars minor ("Donatus"). [Mainz: Johannes Gutenberg(?), c. 1453-54?]; for the earliest fragment in Gutenberg's 42-Line Bible types, preserved in the Scheide Library at Princeton University, see ISTC id00318000. 


\section{The Gutenberg Bible}

The preceding examples taken from early Mainz fragments and booklets may not entirely accord with everyone's definition of books printed for performance. We are on much more solid ground with Gutenberg's 42-Line Bible, produced in Mainz with financial and organizational input from Johann Fust ca. 1450-1455. The Gutenberg Bible is a large book, Royal folio in format, about 16 inches tall, consisting of 643 leaves. Its ample size and large-print Latin text made it particularly useful for the performance of liturgical services (group reading of Lessons and Psalms during the Night Office, according to the ordo librorum) and refectory reading (group reading by monks at all meals, as prescribed by St. Benedict's rule 38). In fact, only two of the 48 largely intact surviving copies of this Bible, now located at the Hofbibliothek in Aschaffenburg and the New York Public Library, exhibit signs of extensive use for private study in libraries - that is, marginal annotations for theological explanations and interpretations. ${ }^{8}$ The great majority of early markings in Gutenberg Bibles are for liturgical or refectory readings in accordance with the liturgical calendar. We now know that copies of this Bible were owned at an early date by the Benedictines of Mainz, Würzburg, Andechs, Trier, Saint-Omer, and Melk, the Augustinians of Rottenbuch, Rebdorf, and Colmar, the Franciscans of Altenburg and Langensalza, the Dominicans of Silos, the Carthusians of Erfurt and Mainz (the heavily annotated copy in Aschaffenburg), the Carmelites of Heilbronn, the Cistercians of Arnsburg, the Brigittines of Soest and Vadstena, and the Sisters of the Common Life at Immenhausen, while evidence in several other copies points either to specific churches or to less certain monastic provenances. ${ }^{9}$

A handy, typical piece of evidence of liturgical reading from a Gutenberg Bible is found in Bridwell Library at Southern Methodist University, the home of 31 consecutive leaves of the Book of Jeremiah from the "Trier II" copy of the Gutenberg Bible. ${ }^{10}$ This copy, originally owned by the Benedictines of St. Maximin in Trier, was divided and partially lost during the sixteenth century, was severely damaged in Napoleonic times, and was transferred in 1828 to Trier's municipal library, which already held another copy. During the German depression it was sold as a "duplicate" to the Jewish chemist Maximilian Wiernik, who in 1937 placed it with Sotheby's in London so that he could reclaim the proceeds from its sale once he escaped from

7. A superb English overview is provided by Janet Ing, Johann Gutenberg and his Bible: A Historical Study (New York: The Typophiles, 1988).

8. Donald Cleveland Norman, The 500th Anniversary Pictorial Census of the Gutenberg Bible (Chicago: The Coverdale Press, 1961) provides a photographic record of nearly every copy of the Gutenberg Bible.

9. Ing, Johann Gutenberg and his Bible, 109, lists several of these monastic provenances; Needham, "The Changing Shape of the Vulgate Bible," 68-69, note 22, lists the eight monastic orders that owned Gutenberg Bibles and gives further bibliography; newly discovered monastic provenances will be discussed in my forthcoming book, Editio princeps: A History of the Gutenberg Bible.

10. For the story of this Bible's dispersal as fragments and individual leaves, see Eric Marshall White, "Long Lost Leaves from Gutenberg’s Mons-Trier II Bible," Gutenberg-Jahrbuch 77 (2002): 19-36. 
Nazi Germany. Sotheby’s sold the volume to Arthur Houghton, Jr., who exchanged it in 1951 as partial payment for the superior copy owned by Charles Scribner's Sons booksellers in New York, a copy that is now in Mainz. Scribner's dismantled the incomplete Trier II copy in 1953, selling the individual books and single leaves to numerous collectors. Several manuscript markings within the Book of Jeremiah at Bridwell Library illustrate how this copy was used for monastic readings during the Night Office (marked "nox") during the last fortnight of Lent. For example, "finis chori" and "finis lectionum" ("here ends the reading") marked the endings of two passages in the book of Jeremiah that were read aloud in the church choir (see figures 2 and 3). These are directions for carefully scheduled biblical readings that were an essential part of monastic worship.

Figure 2. Biblia latina ("The 42-Line Bible") [Mainz: Johannes Gutenberg, for Johann Fust, ca. 1455]; vol. II, f. 71 recto (detail, beginning of Jeremiah 2). Courtesy of Bridwell Library Special Collections, Perkins School of Theology, Southern Methodist University.

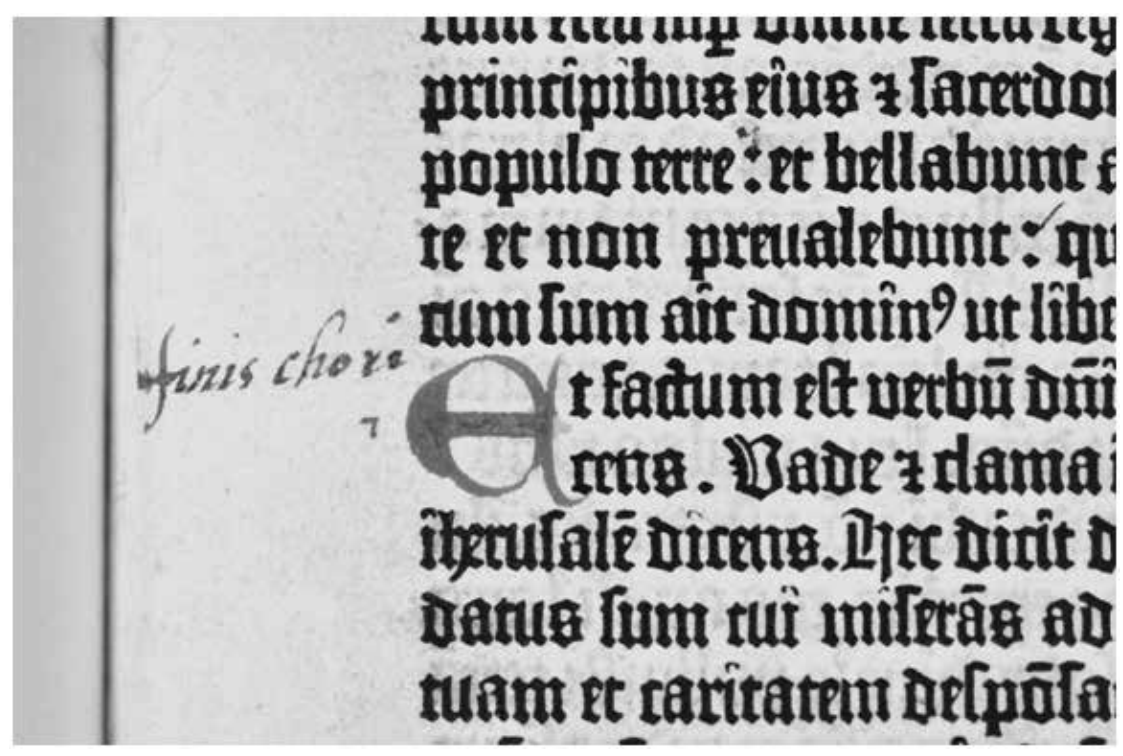

The most thoroughly marked-up copy of the Gutenberg Bible is at the University of Texas in Austin. As I demonstrated in 2005, this Bible was used for liturgical reading at an unidentified Carthusian monastery, probably in south Germany, during the fifteenth century. ${ }^{11}$ The words "In refectorio" mark many passages that were to be read aloud at meals. Throughout, other passages were numbered in the margins 1 through 8 for reading aloud in church during the eight canonical hours of the monastic day. For those years in which Christmas and New Year's Day fell

11. Eric Marshall White, "The Gutenberg Bible at the Harry Ransom Center: Description and Analysis," in The Gutenberg Bible at the Harry Ransom Center: CD-ROM Edition (Austin: University of Texas, 2005). 
Figure 3. Biblia latina ("The 42-Line Bible") [Mainz: Johannes Gutenberg, for Johann Fust, ca. 1455]; vol. II, f. 75 recto (detail, end of Jeremiah 8). Courtesy of Bridwell Library Special Collections, Perkins School of Theology, Southern Methodist University.

\section{Frulptilitbs Luita: $z$ in uanitatibug alie;

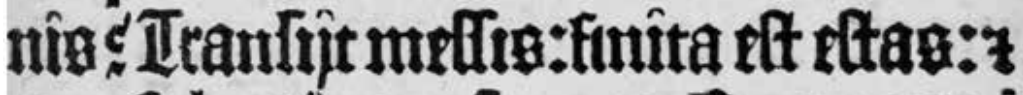 nog faluati non fumug. Bux rontri= tione flie wh mti cantrito lum $z$ ron=

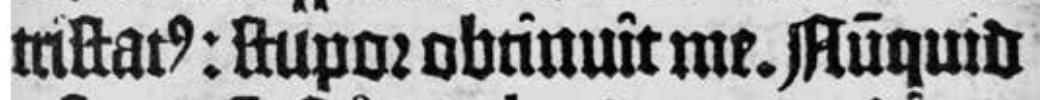

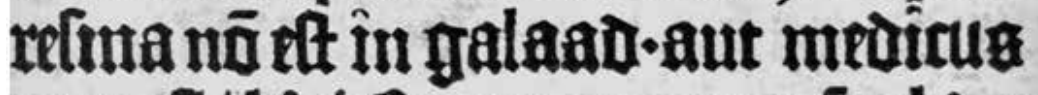 nou eft ibi : Duare rtuonane nbiu= ta ritattix fllix populi meís finis tuctio}

upon Sundays, the readings were marked alphabetically, A through H. Other sections were marked $P[$ rima $], S[$ ecunda $]$, and T[ertia lectio]: that is, the first, second, and third readings for feast days. The system becomes somewhat complicated, but there is a lengthy Latin explanation written in the Bible itself: "When the Dominical Letter is A, follow the markers A, B, C for the feast days. For all other times follow the headings $\mathrm{P}, \mathrm{S}$, and T; and on normal Sundays follow the numerals I, II, III, and so on; the sacristan must take care that the readers make no mistakes in determining the readings." This systematic biblical reading schedule was set down in the Statutes of the Carthusian Order; thus, the same marginal notation system appears in Carthusian Bible manuscripts and in two other Gutenberg Bibles that were owned by the Carthusian monasteries of Mainz (now at Aschaffenburg) and Erfurt (at Eton College). Several other copies feature unidentified marginal lection notes. Clearly, worship that was choreographed to such a degree was no less of a performance than what is preserved in special collections dedicated to theater, film, music, and dance.

Most of the features of the Gutenberg Bible that we have discussed to this point were added by hand, post-production. What, if anything, did Johannes Gutenberg do at the press for the sake of liturgical reading? First of all, he created a large, beautiful, easily legible Gothic typeface, almost as large as that in the Sibyllenbuch, but more elegant and attentive to the conventions of contemporary script. This user-friendly feature was mentioned in the earliest report 
of the Gutenberg Bible that we have: a letter of 1455 in which Aeneas Silvius Piccolomini (the future Pope Pius II) told his friend Cardinal Juan de Carvajal that he had encountered a "miraculous man" at the Imperial Diet in Frankfurt who had something like 180 Bibles for sale. He wrote of the Bible, "your Grace could read it effortlessly, even without glasses." 12 Effortless reading is essential in religious services. Gutenberg also arranged the page beautifully for public reading, organizing the text around amply spaced initials, and composing lines that are not so long that they tire the eye. Moreover, when the text states that King Antiochus invaded Israel in the 143rd year (I Maccabees 1:20), instead of expecting the reader to figure out what a Roman numeral such as CXLIII might be in the middle of a reading, Gutenberg spelled out the numbers ("centesimo et quadragesimo et tercio") so that the reader could simply say each syllable without having to do the math. Finally, Gutenberg helped out the reader by never ending any of the 1,282 printed pages in the middle of a hyphenated word. Just as in a musical performance, felicitous page turns are crucial in scriptural readings during worship services.

\section{Three Mainz Psalters}

Shortly after the completion of the Gutenberg Bible ca. 1455, its types were used to print a 42-line edition of the Psalterium cum canticis: that is, the 150 Psalms with hymns for liturgical use outside the context of the Bible. This folio book, originally about forty leaves in length, survives in a single vellum leaf now at the Bibliothèque Nationale in Paris. ${ }^{13}$ The main difference between this printing of the Psalter and that found within the Gutenberg Bible, aside from the addition of liturgical hymn texts, is the ordering of the Psalms not in their biblical order, but in the drastically different order of their recitation in church services throughout the liturgical year. Clearly, no one sat down to read the Psalms silently in their liturgical order and recited the accompanying chants in his head. These Psalms and hymns were performed out loud in the belief that they could be heard on high—in church.

Perhaps the most visually spectacular example of the use of an early printed book in liturgical services is the Psalterium cum canticis, the first explicitly dated work of European typography, completed in Mainz by Gutenberg's former colleagues Johann Fust and Peter Schoeffer on 14 August $1457 .{ }^{14}$ The first thing that one notices about this beautiful Book of Psalms with hymns arranged for the liturgy is its enor-

\footnotetext{
12. This translation is based on Martin Davies, "Juan de Carvajal and Early Printing: The 42-Line Bible and the Sweynheym and Pannartz Aquinas," The Library, 6th ser., 18, no. 3 (Sept. 1996), 196; see also Ing, Johann Gutenberg and his Bible, 66-68.

13. Psalterium cum canticis ("Liturgical Psalter") [Mainz: Johann Fust and Peter Schoeffer(?), c. 1455]; see ISTC ip01035900.

14. Psalterium cum canticis [Mainz: Johann Fust and Peter Schoeffer, 14 August 1457]; see ISTC ip01036000.
} 
Figure 4. Psalterium Benedictinum cum canticis et hymnis [Mainz: Johann Fust and Peter Schoeffer, 29 August 1459]; f. 43 verso (Psalm 68).Courtesy of Bridwell Library Special Collections, Perkins School of Theology, Southern Methodist University.

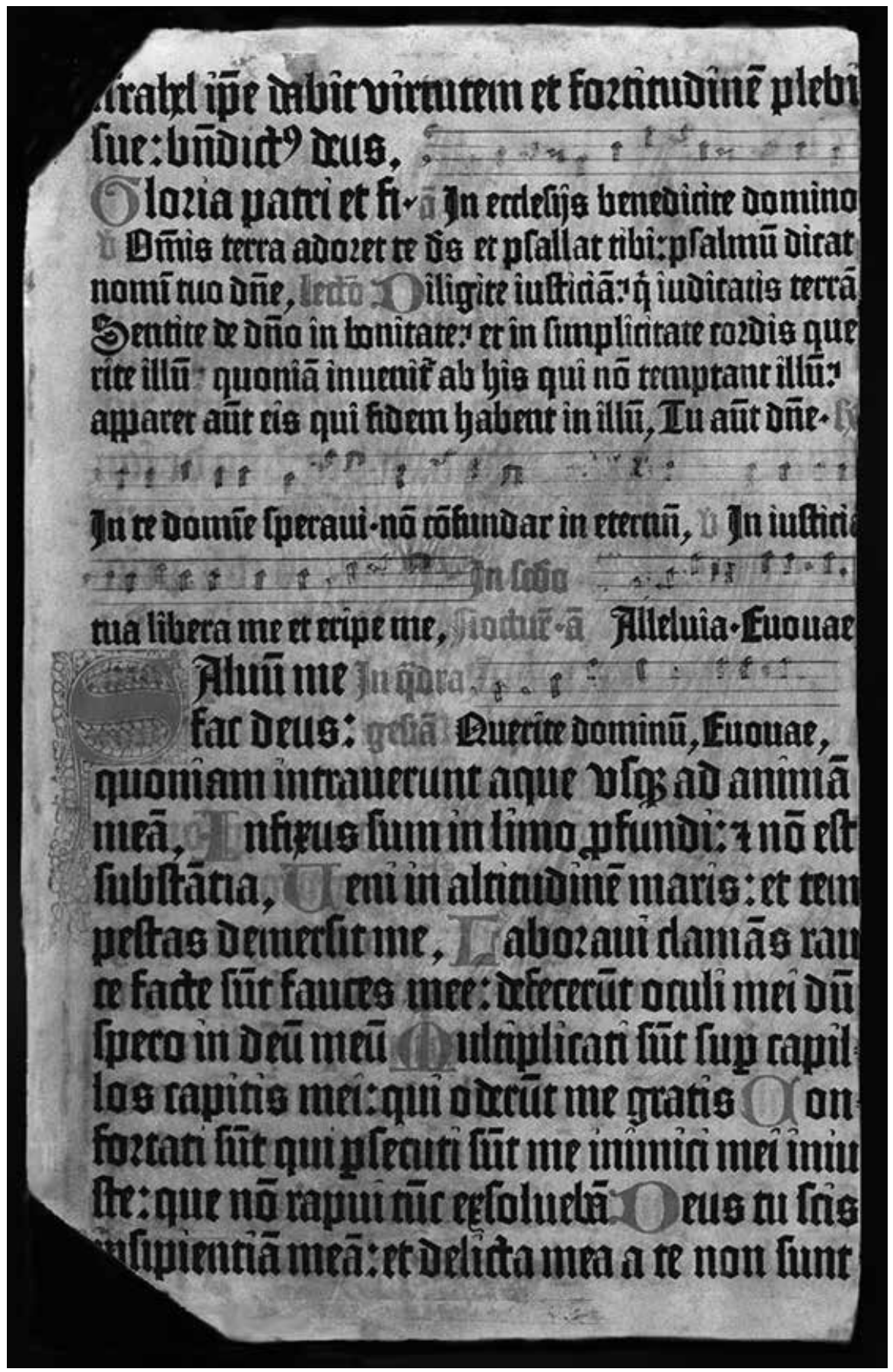


mous decorative initials, printed in red and blue. ${ }^{15}$ These are not simply ornamental; they introduce the individual psalms and help the users of the Psalter find their way. The users were mostly monastic choristers within the Archdiocese of Mainz, who would recite all 150 of the psalms during each week's daily liturgical services. Therefore, the Psalter had to be a book that was easy to use. It was printed in very large Gothic letters that are more than twice as tall as those of the Gutenberg Bible for no other reason than that the text had to be large enough to be read by several choristers gathered around a lectern. The Psalter of 1457 was also the first book printed expressly to accommodate musical performance, as large blank spaces were left throughout for the insertion of musical notation by hand.

The large folio Psalterium Benedictinum published in Mainz by Fust and Schoeffer on 29 August 1459, printed for use within Benedictine monasteries in essentially the same manner as the smaller Mainz Psalter of 1457, was the fourth European book of extensive length to come from the printing press (see figure 4). ${ }^{16}$ Illustrated here is a single leaf from this book, acquired in 2006 by Bridwell Library. Although this is only a fragment of a now unobtainable book (only two copies of the intact Psalter of 1459 are preserved in the United States), the Bridwell leaf is a wonderfully useful tool for bibliographical instruction whenever the library hosts classes or visitors interested in early printing. Again, the Psalter's immense size and large typeface facilitated use by several choristers gathered around a lectern, and musical staves were added in manuscript so that the book could be used in the daily liturgical recitation of the psalms accompanied by the singing of hymns.

\section{The Canon Missae}

In terms of interactive use, no book from the Fust and Schoeffer press was more remarkable than the Canon missae of ca. $1458 .{ }^{17}$ This twelve-leaf fascicle, printed on vellum, was intended to be inserted into folio-format manuscript Missals to ensure liturgical conformity by means of a common printed text. Indeed, all three of the copies that survive, preserved at the Bodleian Library in Oxford, the Austrian National Library in Vienna, and Columbia University's Butler Library, were discovered within early Missals. The Canon missae was the sacred text used by a priest during the holiest part of the Mass ceremony, the Canon of the Mass, which included the miraculous moment of transubstantiation followed by the consumption of the sacramental bread and wine. Like the Psalters of 1457 and 1459, the Canon missae featured rubrics printed in red ink, but here instead of being mere headings, they indicate specific

15. Irvine Masson, The Mainz Psalters and Canon Missae 1457-1459 (London: The Bibliographical Society, 1954).

16. Psalterium Benedictinum cum canticis et hymnis. [Mainz: Johann Fust and Peter Schoeffer, 29 August 1459]; see ISTC ip01062000, and Masson, The Mainz Psalters and Canon Missae.

17. Canon missae. [Mainz: Johann Fust and Peter Schoeffer, c. 1458]; see ISTC im00736000, and Masson, The Mainz Psalters and Canon Missae, esp. 65-72. 
ritual actions to be performed by the celebrant. For example, the rubric on the leaf 7 recto, "hic fit memoria vivorum," tells the priest to pronounce the names of the living souls whom he wishes to remember in this solemn prayer. Bear in mind that the rubrics themselves are never read out loud; they are directions for performance. On the same page, the three red crosses that appear in the middle of the words do na, munera, and sancta sacrificia at the beginning of the Canon of the Mass are signals for actions to be performed as well. Known as the "croix pattée," this cross marks the moment at which the priest must physically make the sign of the cross at the altar as he pronounces the three Latin words for God's holy gifts, holy munificence, and holy sacrifice. Other rubrics in the Canon missae take on a role even more like stage directions. On leaf 2 verso the rubric reads "Hic erigat se \& osculetur altare \& vertit se ad populum," which tranlsates "Here the priest shall raise himself and kiss the altar and turn to the people." Further down on the same page, the rubric "vel" (Latin for "or") printed between the words "noctem" and "diem" gave the priest the option of saying "night" or "day," depending on the liturgical circumstances.

The typographic innovations of the early Mainz printers have had their longest afterlife in liturgical books, which to this day print the rubrics in red, include the "croix pattée," and often set off the Canon of the Mass in larger letters. Despite centuries of liturgical reform and the adoption of new practices, a fifteenth-century priest probably would have little trouble using one of today's printed Missals, and one of today's Catholic priests should be able to make sense of a fifteenth-century Missal. At the center of the Catholic Mass is a remarkably unchanged sacred ritual in which the body of Christ is believed to become a miraculous but physical presence. But what happens if the priest does not have the sacred liturgical book that has been written or printed for this ceremony, but instead has access only to a digitized or online version of the liturgy? There is at present considerable debate over the use of electronic surrogates in the celebration of the Mass. The Roman Missal for iPad was recently developed by the Rev. Paolo Padrini (known as "Priest 2.0"), a consultant with the Vatican's Pontifical Council for Social Communications. ${ }^{18}$ This is meant to be part of the worldwide outreach of the Catholic Church, which is actively espousing the use of the Internet and social media in its evangelizing work. However, many Catholic leaders remain hesitant to embrace innovative technologies in the conduct of the ancient sacraments and rituals. Bishop Joel Zamudio Baylon, a member of the Catholic Bishops' Conference of the Philippines, personally discourages his fellow priests from using electronic Bibles or Missals. Bishop Baylon points out that, unlike a real Bible or a real Missal, the iPad or other devices were not made exclusively for the sacramental ceremony. One might say they were

18. Domenico Agasso, Jr., "Scriptures on your Smartphone” Vatican Insider, posted online January 31, 2012, available online at http:/ / vaticaninsider.lastampa.it/en/inquiries-and-interviews/detail/articolo/ tecnologia-fede-12178/. 
not born Eucharistic. To quote Bishop Baylon: "The iPad is not appropriate for the sanctity of the altar. It can be both secular and mundane, making it unfit to replace the Missal or the other books that are set aside for the Liturgy, and the books that are made only for the altar." ${ }^{\prime 19}$ However, the Bishop concedes that, while the iPad should not be for regular use, it can be used during "extraordinary" circumstances, such as during travel, or because of lack of access to a real Bible or Missal. It seems that the printed Missal is likely to retain its traditional central role in liturgical performance.

Similarly, many of the key functional aspects of printed Bibles established in the mid-fifteenth century are not easy to retain in digital formats. In 1989, the first computerized Bible arrived: the Franklin electronic hand-held King James Version of the Bible. Besides its novelty, its greatest selling point was that the entire text of the English Bible was searchable. But, being a computerized gadget, it had an image problem. While a digital Bible may be well suited to quick reference and personal study, or reading on the subway (which one sees more and more often), it is safe to say that few worshippers would prefer to use one for Lessons or Gospel readings during church services. There are all kinds of digital Bibles-some even use page-turning software so as to pretend to be books all over again — but something ceremonial and sacred has been lost in translation.

For the sake of context and contrast, it is worth considering the earliest works in the European typographic tradition that demonstrably were not printed for an audible interactive function. The earliest of these appear to be the Indulgences dated 1454 and 1455, which were simply small single-sheet forms printed as promissary notes for early release from purgatory in exchange for financial donations and sincere penance. Next in date were the single-sheet calendrical broadsides known as the Cisioianus of ca. 1456 and a blood-letting schedule for the use of physicians in the upcoming year 1457. Next came the Bulla Turcorum by Pope Calixtus III, published in twelve-leaf Latin and fourteen-leaf German quarto editions in 1456 (these arguably were intended primarily for an initial public pronouncement), and the eight-leaf quarto Provinciale Romanum, a list of every archdiocese in Europe, published ca. 1456-1457. About one year later, a German broadside for casting horoscopes was printed in Mainz.

It is somewhat ironic that the first book of significant length printed for solitary study in silence while seated at one's desk was the Rationale divinorum officiorum by Guillelmus Durandus, a text that is largely concerned with the performance

19. Kris Bayos, "Bishop advices [sic] use of iPad, tablet in lieu of Missal only during 'emergency'," Youth Pinoy, posted online August 10, 2012, available online at http:/ / youthpinoy.com/bishop-advicesuse-of-ipad-tablet-in-lieu-of-missal-only-during-emergency/. 
of Christian rituals and ceremonies. ${ }^{20} \mathrm{~A}$ handsome folio published in Mainz by Fust and Schoeffer on 6 October 1459, this immense thirteenth-century compendium was the first book printed in Europe with a very small typeface. Based on a rounded script favored by humanists for their scholarly works, this new font allowed for continuous, close reading with the book a few inches under one's nose. The scholarly function of the small Durandus font was imitated in two brief theological tracts printed in Mainz ca. 1459-1460, St. Thomas Aquinas's De articulis et ecclesiae sacramentis and Matthias de Cracovia's Dialogus rationis et conscientiae de frequenti usu communionis, both printed with the small humanist typeface that would appear in the lengthy Latin dictionary known as the Catholicon, printed in Mainz and dated "1460." 21 These works are convincingly attributed to Gutenberg's second press. While liturgical printing with Gothic fonts remained an important industry, the increasing majority of books printed during the 1460s and subsequent decades were theological works, classical texts, and scholarly literature designed for sustained reading.

\section{The Graduale of 1473}

One final example of fifteenth-century printing for performance will demonstrate how early printers met the challenge presented by the necessity of including musical notation in liturgical books. We have seen that musical notation in the Psalters of 1457 and 1459 had to be added by hand. The first surviving printed music appeared ca. 1473 in a handsome Graduale, formerly but mistakenly assigned to the Diocese of Constance. ${ }^{22}$ This small folio hymnbook, 160 leaves thick, has printed musical staves on nearly every page, and close analysis confirms that the musical notation was produced with movable metal types, not with woodblocks or any other means. The Graduale of ca. 1473 ought to be familiar to every special collections librarian: it is the Gutenberg Bible of printed music, not quite as innovative or important as the Gutenberg Bible, but 48 times more rare. One complete copy has been preserved at the British Library since 1846, while a fragment survives at the University of Tübingen. The Graduale is an impressive technical achievement. The printed parts are in black ink; this first leaf recto has seven staves of five lines paired with Gothic text; the large initials A and U were added by hand in red ink,

20. Guillelmus Durandus, Rationale divinorum officiorum [Mainz: Johann Fust and Peter Schoeffer, 6 October 1459]; see ISTC id00403000.

21. Giovanni Balbi, Catholicon [Mainz: Printer of the Catholicon (Johannes Gutenberg?), 1460]; see ISTC ib00002000. Paul Needham, "Johann Gutenberg and the Catholicon Press," Papers of the Bibliographical Society of America 76 (1982): 395-456, has shown that the paper supplies used in the second and third issues of the Mainz Catholicon (ca. 1469-73), and the slight shifting of two-line units of the otherwise identical text, indicate that they must have been printed not with movable type but with stereotype castings made from the original setting that was dated "1460."

22. Graduale [Southern Germany: "Printer of the Constance Breviary," ca. 1473]; see ISTC ig00329700, and Alec Hyatt King, "The 500th Anniversary of Music Printing: The Gradual of c1473," Musical Times 114 (1973): 1220-23. 
while the smaller initial V of the second verse was printed. The first hymn is "Ad te levavi animam meam" ("To you, O Lord, I lift up my soul"), from Psalm 25, while the rubric written at the top of the page identifies the liturgical function of this hymn, the Introit for the first Sunday in Advent. Thus, the hymnbook commences at the beginning of the liturgical year.

The technical achievement of this Graduale was not merely the effective spacing of the musical notation but also the correct registration of the notes and the printed staff, which required two runs through the press. The text and blank staves were printed first, then the diamond-shaped notes in just the right locations on the lines or in the spaces. In fact, the printers did a better job with the notation than they did with the text, which looks a bit inelegant for 1473. At either side of the staves, printed vertical double rules (derived from the manuscript tradition) help to organize the page, while printed symbols indicate the $\mathrm{F}$ and $\mathrm{C}$ clefs. The rubricator has highlighted the line for the F clef in red throughout so that the singers may keep track of that pitch when it migrates from the fourth line to the fifth line, or when it shifts upward midway through the sixth staff, where the gradual hymn "Universi qui te expectant" begins. Each musical staff ends with a special direction note known as a custos. Not to be sung out loud, the custos indicates to the singer where the pitch will continue on the next line. These special features, derived from manuscript practices, confirm that the music in the Graduale of ca. 1473 was designed for live musical performance in a liturgical ceremony.

\section{Conclusion}

We have already mentioned the image problem that electronic surrogates face when their use in religious ceremonies is proposed. The iBreviary, a liturgical "book" of Catholic rites containing the public or canonical prayers, hymns, psalms, and other readings for everyday use, was developed by Rev. Padrini in 2009, but its sales have suffered from both poor technical reviews and a desire on the part of the clergy to stick to tradition in ritual matters. But, with musical performance, there is perhaps a greater upside to using electronic versions. My twelve-year-old son's band director has him practicing trombone with on-screen online musical scores and interactive evaluative lesson programs. Several screen-based music reading systems designed for practice and performance are now on the market, and their use of horizontally scrolling musical scores promises to bring an end to centuries of frustration from unwieldy and nightmarish page-turns. One such brand now available for various computer platforms is "PhonicScore - the music stand that listens," which "turns a tablet computer into a digital, intelligent music stand." Ironically, by using interactive sound-sensitive software that moves the musical notation across the screen as the live performance proceeds, this new technology functions more like a scroll than a codex. Here the advantages of a writing technology even more 
ancient than that of the book come to the fore. Still, the traditional functionality of the book is a strong force to overcome. Whereas printed music came along less than twenty years after the Gutenberg Bible, we are now decades into the availability of small computers and the Internet, yet virtually no one performs classical music from electronic scores in formal concerts. It is interesting that, in our own time, when seemingly every form of media needs to be "new-point-oh," the adoption of high-tech innovations in liturgical and musical performance has proceeded no faster than the speed with which the creaky old printing press introduced itself into the world of manuscripts 560 years ago. Perhaps we have something to learn from the performance of Gutenberg and his colleagues after all.

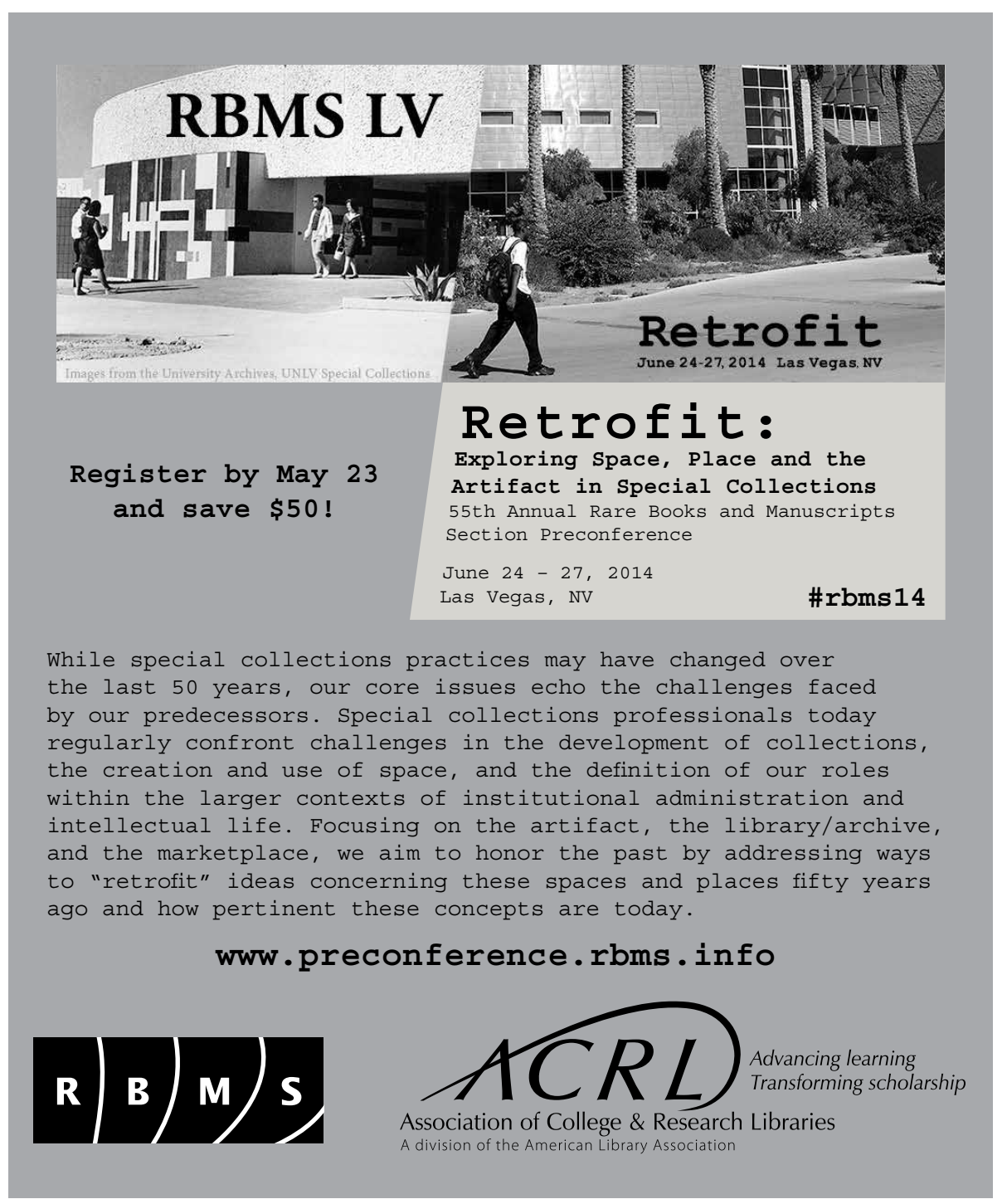

